Jurnal Teknologi Informasi dan Ilmu Komputer (JTIIK)

Vol. 2, No. 1, April 2015, hlm. 59-66

\title{
GAME SIMULASI WIRAUSAHA BERBASIS MODEL PEMBELAJARAN EKSPERIENSIAL SEBAGAI ALTERNATIF MEDIA PEMBELAJARAN DI SMK KELAS XI
}

\author{
${ }^{1}$ Yulian Findawati, ${ }^{2}$ Suprianto, ${ }^{3}$ Wiwik Sumarmi \\ ${ }^{1,2}$ Teknik Informatika, Universitas Muhammadiyah Sidoarjo \\ ${ }^{3}$ Teknik Industri, Universitas Muhammadiyah Sidoarjo \\ Email : ${ }^{1}$ yulianfindawati@umsida.ac.id, ${ }^{2}$ Suprianto@umsida.ac.id, ${ }^{3}$ Wiwik Sumarmi@umsida.ac.id
}

(Naskah masuk: 29 Januari 2015, diterima untuk diterbitkan: 17 Februari 2015)

\begin{abstract}
Abstrak
Salah satu model pembelajaran yang menarik dan kreatif yaitu model pembelajaran Game. Adapun game yang dimaksud adalah game simulasi yang disesuaikan dengan mata pelajaran kewirausahaan pada SMK kelas XI. Game simulasi wirausaha yang dibuat berupa game berbasis model pembelajaran eksperiensial dimana game ini memberikan pengalaman bagi pemain game sebagai wirausahawan muda yang ingin mengembangkan usaha. Di dalam game ini juga disesuaikan dengan kurikulum SMK kelas XI pada mata pelajaran kewirausahaan, dimana yang disimulasikan berupa pengalaman perijinan usaha, manajemen produksi , manajemen pemasaran, pencatatan transaksi keuangan dan pelayanan pelanggan. Pengujian validasi game simulasi dilakukan oleh ahli media ahli materi dan siswa menggunakan kuisioner. Dari pengujian yang dilakukan oleh ahli media, game simulasi ini memiliki nilai sangat bagus pada keterbacaan tulisan teks, ketepatan ukuran huruf, ketepatan warna huruf, ketepatan jenis huruf, kejelasan tata letak gambar, kesesuaian tampilan, penempatan konten, ketepatan penggunaan tema, dan kualitas tampilan desain. Sedangkan berdasar pengujian yang dilakukan oleh ahli materi maka yang memiliki nilai baik yaitu pada poin kebenaran materi, kemenarikan materi, keruntutan materi, cakupan materi..Berdasarkan uji kelayakan yang diujikan kepada siswa maka Game simulasi ini mampu menarik siswa sebagai pengguna Game simulasi wirausaha di dalam memahami pembelajaran kewirausahaan pada SMK kelas XI.
\end{abstract}

Kata Kunci : Game Simulasi, Wirausaha, Media pembelajaran

\begin{abstract}
One model of learning interesting and creative the model of learning games. As for the game in question is a simulation game that is tailored to the subjects of entrepreneurship in vocational class XI. Entrepreneurial simulation game that is made in the form of experiential learning model based games where the game provides an experience for gamers as young entrepreneurs who want to develop business. Also in the game adapted to class $X I$ vocational curriculum in the subjects of entrepreneurship, where a simulated form of experience in licensing, production management, marketing management, recording of financial transactions and customer service. Validation testing simulation games conducted by media experts, subject matter experts and students using a questionnaire. From the testing conducted by media experts, game simulation makes the value very good in readable text, the accuracy of the size of the font, color accuracy letters, accuracy typeface, clarity of image layout, the suitability of view, the placement of the content, the accuracy of the use of themes, and display quality design. While based on tests performed by the subject matter experts who have good grades, namely the truth of the material points, the attractiveness of the material, the material keruntutan, materi..Berdasarkan coverage feasibility test students tested in the simulation game is able to attract students as entrepreneurial simulation game users in understand entrepreneurial learning in vocational class XI.
\end{abstract}

Keywords: Simulation Game, Entrepreneur, Media Learning

\section{PENDAHULUAN}

Mata pelajaran kewirausahaan sebagai salah satu mata pelajaran di SMK berfungsi membekali siswa dengan pengetahuan dan keterampilan dasar agar siswa mampu membuka lapangan pekerjaan sendiri setelah lulus dari SMK yang Sejalan dengan Renstra Kementrian Pendidikan Nasional pada Road Map Pengembangan SMK 2010-2014. Selama ini bacaan model pembelajaran kewirausahaan masih bersifat text book. Sehingga siswa mudah bosan dan jenuh di dalam menyerap materi kewirausahaan kelas XI. Menurut Strangman \& Hall (2003) yang menyatakan bahwa Game komputer menjadi sebuah pendekatan yang efektif untuk menigkatkan pembelajaran siswa.

Salah satu model pembelajaran yang menarik dan kreatif yaitu model pembelajaran Game komputer yaitu Game simulasi. Permainan Game wirausaha juga merupakan alat bantu dari jenis pembelajaran yang disebut pembelajaran eksperiensial(Moeis A.O, 2005). Model pembelajaran seperti ini mengajak pesertanya untuk mengalami sendiri secara langsung apa yang mereka pelajari tersebut. Dalam penelitian ini, yang ingin dibuat adalah sebuah Game simulasi kewirausahaan bagi SMK kelas XI. Game simulasi 
ini berbasis model pembelajaran eksperiensial yaitu belajar sebagai proses dimana pengetahuan diciptakan melalui transformasi pengalaman sehingga pengguna merasa terlibat dengan kegiatan kewirausahaan secara langsung dengan cara memposisikan pengguna untuk memerankan tokoh wirausaha yang sedang menjalankan usaha toko cupcakenya dimana tokoh wirausaha ini akan menyelesaikan permasalahannya . Game simulasi wirausaha yang disesuaikan dengan kurikulum SMK kelas XI pada mata pelajaran kewirausahaan, dimana yang disimulasikan adalah perijinan usaha, manajemen produksi dan manajemen pemasaran.

Oleh karena itu, penulis mengangkat penelitian berupa pengembangan Game simulasi menjalankan toko usaha cupcake dengan materi Game menjalankan manajemen produksi, perijinan usaha, dan manajemen pemasaran yang disesuaikan dengan kurikulum SMK kelas XI. Adapun tujuan penelitian ini sangat penting karena sebagai upaya bahan alternatif media pembelajaran kewirausahaan di SMK kelas XI dan Meningkatkan kualitas pembelajaran kewirausaahaan pada SMK kelas XI . Game simulasi wirausaha memposisikan pengguna Game untuk memerankan tokoh/karakter calon wirausaha yang akan mengetahui permasalahan di dalam kewirausahaan dan menyelesaikan masalah yang dihadapi calon wirausaha seperti langkahlangkah perijinan usaha, manajemen pemasaran dan manajemen produksi yang disesuaikan dengan kurikulum SMK kelas XI.

\section{TINJAUAN PUSTAKA}

\section{Game Edukasi}

Menurut Virvou (2005) teknologi Game (edukasi) dapat memotivasi pembelajaran dan melibatkan pemain, sehingga proses pembelajaran lebih menyenangkan. Demikian pula hasil penelitian yang dilakukan oleh Randel pada tahun 1991, tercatat bahwa pemakaian Game sangat bermanfaat pada materi-materi yang berhubungan dengan matematika, fisika dan kemampuan berbahasa (Dillon, 2004)

\section{Kewirausahaan}

Program kewirausahaan di SMK pada dasarnya merupakan salah satu program pembelajaran yang bertujuan untuk penanaman nilai kewirausahaan melalui pembiasaan, penanaman sikap, dan pemeliharaan perilaku wirausaha(Lastarawati, 2012)

\section{Metode pembelajaran Eksperiensial}

Menurut Kolb (1984), mendefinisikan model pembelajaran eksperiensial adalah belajar sebagai proses dimana pengetahuan diciptakan melalui transformasi pengalaman

Kriteria Penilaian kualitas media pembelajaran Menurut Wahono (2006) terdapat aspek penilaian pada media pembelajaran yaitu diantaranya aspek rekayasa perangkat lunak dan aspek desain pembelajaran

1. Aspek Rekayasa Perangkat Lunak : Efektif dan efisien, kehandalan, Maintainable,Usabilitas Ketepatan pemilihan jenis aplikasi, Kompatibilitas, Pemaketan program media pembelajaran terpadu dan mudah dalam eksekusi, Dokumentasi program media pembelajaran yang lengkap, Reusable

2. Aspek Desain Pembelajaran : Kejelasan tujuan pembelajaran, Relevansi tujuan pembelajaran dengan SK/KD/Kurikulum, Cakupan dan kedalaman tujuan pembelajaran, Ketepatan penggunaan strategi pembelajaran, Interaktivitas, Pemberian motivasi belajar, Kontekstualitas dan aktualitas, Kelengkapan dan kualitas bahan bantuan belajar, Kesesuaian materi dengan tujuan pembelajaran, Kedalaman materi, Kemudahan untuk dipahami, Sistematis, runut dan alur logika jelas, Kejelasan uraian, pembahasan, contoh, simulasi, dan latihan, Konsistensi evaluasi dengan tujuan pembelajaran, Ketepatan dan ketetapan alat evaluasi, Pemberian umpan balik terhadap hasil evaluasi.

\section{METODE PENELITIAN}

Metode penelitian merupakan tahapan-tahapan proses penelitian atau urutan langkah-langkah yang harus oleh peneliti dalam melakukan penelitian. Penelitian ini memiliki tahap-tahap sebagai berikut :

\section{Tahap Penelitian}

Tahap-tahap penelitian dapat dilihat pada Gambar 1 sebagai berikut :

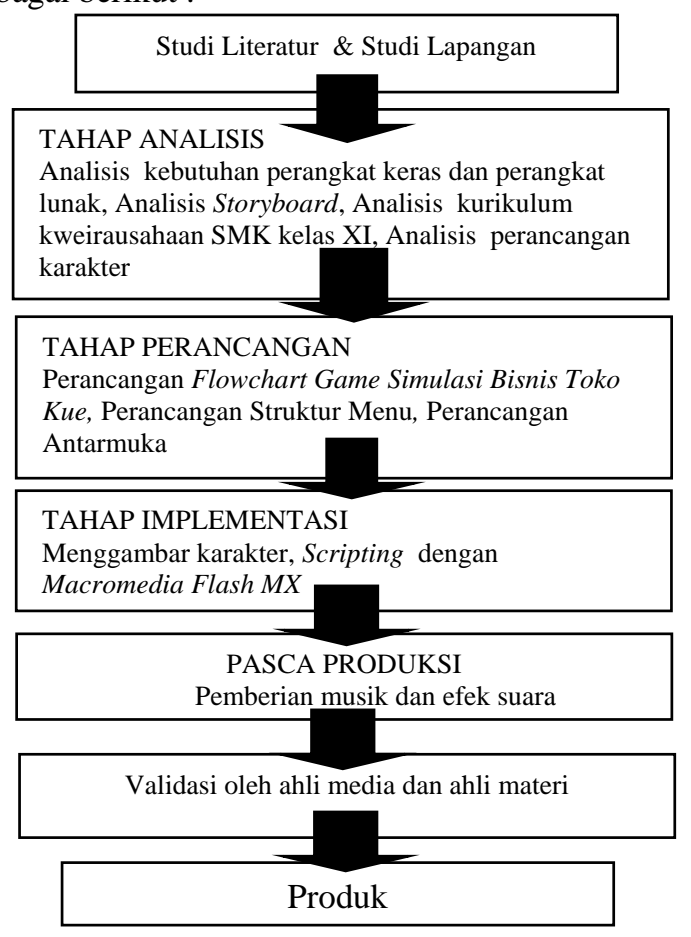

Gambar 1. Tahap - tahap penelitian 
Tahap analisis

Tahap analisis terdiri atas :

1. Analisis kebutuhan

Kebutuhan perangkat keras minimal yaitu Microphone, Laptop Intel Core 2 Duo $2 \mathrm{Ghz}$ untuk membuat Game Simulasi Wirausaha Toko Cupcake menggunakan Macromedia Flash MX .

2. Analisis Storyboard

Tahap ini sangat membantu dalam menyusun frame by frame pembuatan Game simulasi wirausaha toko cupcake dengan materi manajemen produksi, manajemen pemasaran dan perijinan usaha. Dimana Game simulasi wirausaha toko cupcake ini menggunakan alur cerita memerankan tokoh/karakter wirausaha yang akan mengurus perijinan usaha, mengelola produksi , melakukan pemasaran produk serta pelayanan kepada pelanggan secara tepat dan efektif.

3. Menentukan Ide Cerita

Untuk membuat sebuah Game simulasi wirausaha toko cupcake dengan materi manajemen produksi, manajemen pemasaran ,perijinan usaha dan pelayanan pelanggan. yang menarik ditambahkan cerita yang mengiringi Game dimana cerita ini memuat sebgaian kurikulum kewirausaahan pada siswa SMK kelas XI . Ide cerita pada penelitian ini yaitu seorang siswa yang bercita-cita menjadi wirausahawan Toko Cupcake. Adapun ide cerita memuat kurikulum kewirausahaan pada siswa SMK kelas XI yaitu :

a) Menganalisis Peluang Usaha

yaitu mengenai Peluang dan inspirasi usaha, Sumber peluang usaha dan cara mengembangkannya, Faktor-faktor keberhasilan dan kegagalan peluang usahaMemetakan peluang usaha dan Pemanfaatan peluang secara kreatif dan inovatif

b) Menganalisis aspek-aspek perencanaan usaha yaitu mengenai Aspek organisasi usaha sederhana dalam pengelolaan usaha dan Aspek produksi dalam pengelolaan usaha, Perijinan usaha dan Surat menyurat, Pencatatan transaksi barang/jasa dan transaksi keuangan,Pajak, Memahami seni menjual dan Menetapkan harga jual,Menganalisis kepuasan pelanggan, Promosi dan Negoisasi, Saluran dan jaringan distribusi, Memahami permodalan dan pembiayaaan usaha, Memahami rencana anggaran biaya ,Memahami proyeksi arus kas, Menghitung Break event Point, Menghitung Net Present Value dan Internal Rate of return

c) Menyusun proposal usaha

4. Menentukan logline

Setelah logline ditemukan, ditulis sinopsisnya. Sinopsis merupakan gambaran keseluruhan cerita kasar dari sebuah cerita .
5.Membuat Sinopsis

Setelah logline ditemukan, ditulis sinopsisnya. Sinopsis merupakan gambaran keseluruhan cerita kasar dari sebuah cerita yang ditambahkan di Game Simulasi Wirausaha Toko Cupcake. Sinopsis terdiri atas :

1. Dialog sekelompok siswa tentang pengusaha yang mereka sukai beserta alasannya disertai keberhasilan-keberhasilan pengusaha yang menginpirasinya dan quote-quote kiat usaha sukses tersebut

2. Sekelompok siswa yang sedang akan membangun suatu usaha toko cupcake yang sudah berjalan dan ingin memperbesar usaha dengan cara membangun $\mathrm{CV}$ namun mereka bingung bagaimana membangun perijinan usaha, dilanjutkan dengan Game mencari surat-surat yang dibutuhkan di dalam membangun $\mathrm{CV}$ hingga ke tempat pengurusan ijin usaha.

3. Pada sinopsis berikutnya Game ini memberikan permainan penggunaan pinjaman modal yang diberikan oleh bank sebesar Rp.5000.000. Pelaku usaha dalam Game ini akan membelanjakan pinjaman modal untuk pembelian bahan baku produksi, sewa tempat dan pembelian alat-alat pendukung di dalam usaha toko cupcake tersebut.

4. Pada sinopsis berikutnya akan diajarkan Game bagaimana mengolah bahan baku produksi untuk membuat cupcake.

5. Kemudian dilanjutkan dialog pelaku usaha yang berbincang-bincang bagaimana mencatat transaksi keuangan yang baik pada usaha toko cupcake yang sedang berjalan, dan dilanjutkan Game pencatatan transaksi keuangan dimana Game ini mencocokkan transaksi keuangan apakah di debet ata di kredit.

6. Dialog analisis kelayakan bisnis berupa. menghitung Break Event Point, Net Present Value dan Internal Rateof return

7. Dilanjutkan dengan pelayanan pelanggan dengan baik, cepat dan tepat. Di sesi ini siswa telah membuka toko cupcake dan harus melayani pelanggan dalam watu 7 detik dan pesanan cupcake harus sesuai yang dipesan oleh pelanggan.Jika penjualan telah mencapai target yang ditetapkan maka pelaku usaha dapat membeli alat produksi

4. Merancang diagram scene

Secara umum babak awal yaitu berupa perkenalan sekelompok siswa, babak ke dua yaitu berupa materi inspirasi usaha, Game perijinan usaha, pengelolaan modal pinjaman, pengolahan bahan baku produksi, pencatataan transaksi keuangan, analisis BEP, IRR, NPV bisnis, sedangkan babak ke tiga berupa pelayanan pelanggan pada toko cupcake.

5. Pengembangan karakter

Sebuah cerita dipandu dan dimainkan oleh karakter untuk menyelesaikan masalah di Game simulasi wirausaha ini. 
6. Analisis perancangan karakter

Membahas tentang perwatakan dan latar belakang karakter yang berperan dalam Game simulasi wirausaha ini. Dimana karakter utama yaitu seorang wirausaha yang ingin mengembangkan wirausaha toko cupcake-nya.

\section{Tahap perancangan}

Adapun tahap perancangan Game Simulasi Wirausaha Toko Cupcake ini akan digambarkan dalam bentuk use case diagram sebagai berikut :

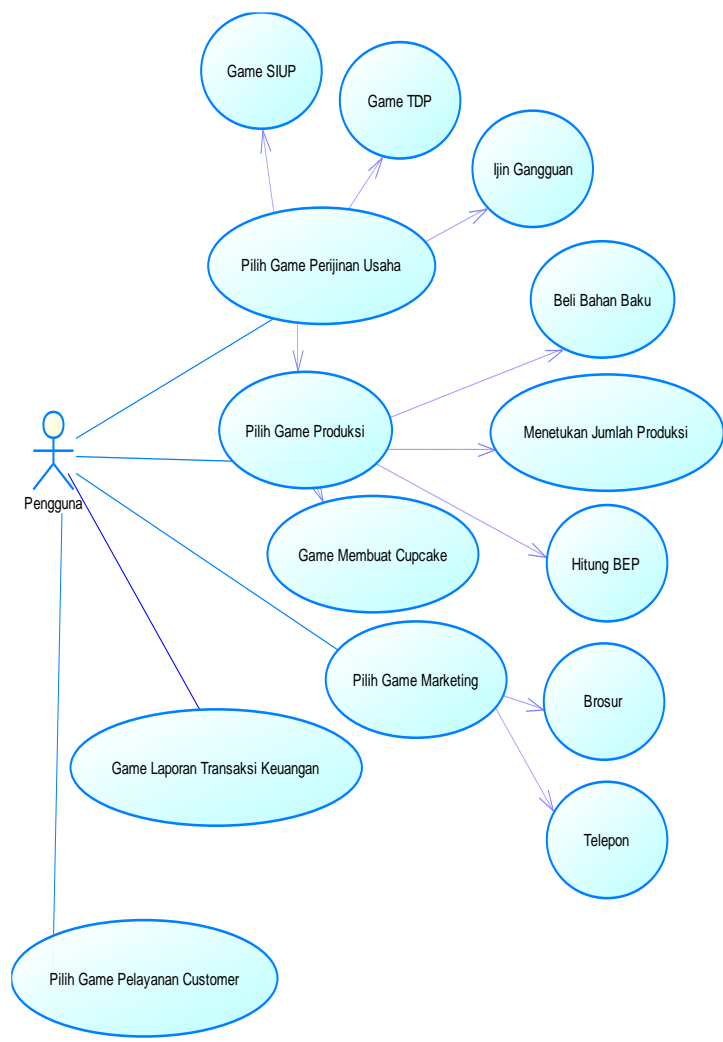

Gambar 2. Use Case Diagram Game Simulasi Wirausaha Toko Cupcake

Gambar di atas menunjukkan macam-macam game yang disajikan dalam game wirasuaha yaitu game perijinan usaha, game produksi, game pemasaran, Game pencatatan transaksi keuangan dan game pelayanan customer.

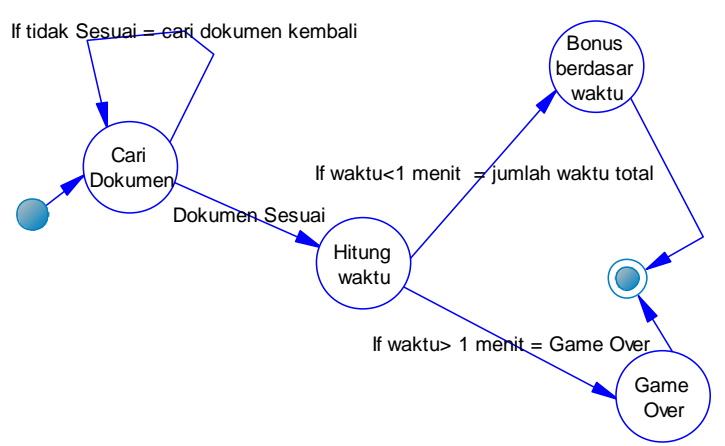

Gambar 3. Diagram automata game perijinan usaha
Gambar di atas menunjukkan langkah-langkan game perijinan usaha.

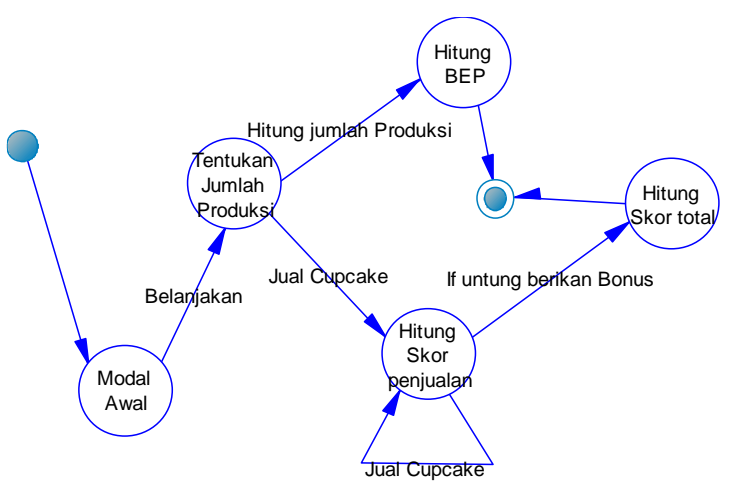

Gambar 4. Diagram automata game produksi .

Gambar di atas menunjukkan langkah-langkah game pembelian bahan baku sampai produksi

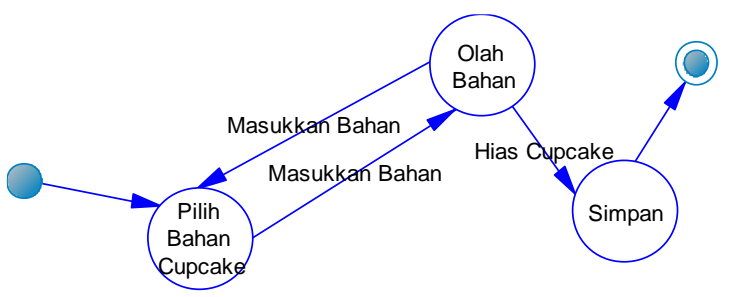

Gambar 5. Diagram Automata game memasak Cupcake

Gambar di atas menunjukkan langkah-langkah memasak cupcake

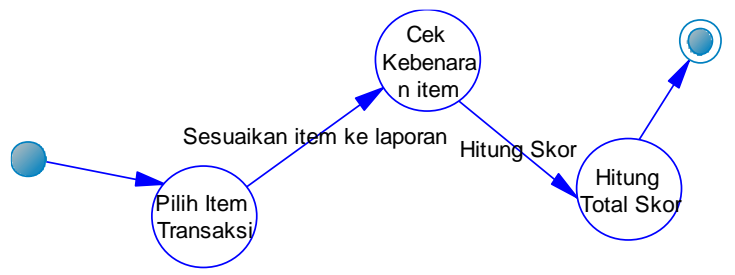

Gambar 6. Diagram Automata game pencatatan transaksi keuangan

Gambar di atas menunjukkan langkah-langkah game pencatatan transaksi keuangan

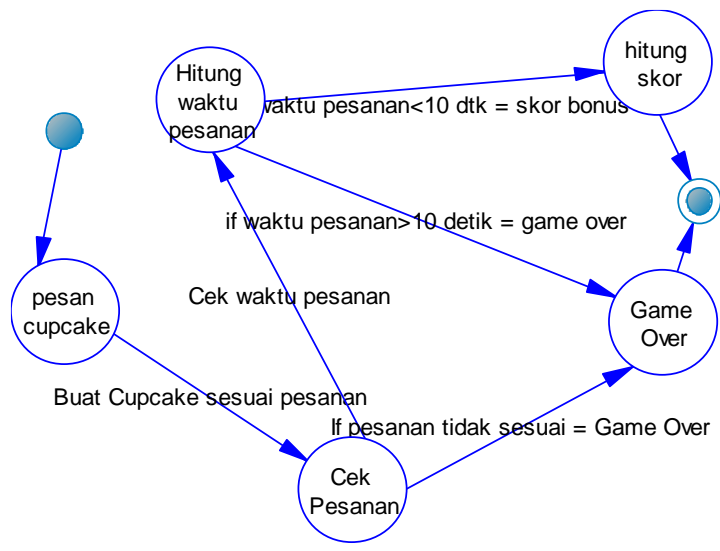

Gambar 7. Diagram automata game pelayanan penjualan 
Gambar di atas menunjukkan langkah-langkah game pelayanan pelanggan

\section{HASIL DAN PEMBAHASAN}

\section{Tahap Implementasi}

Tahap dari implementasi yaitu terdiri atas penanaman visual dan audio. Dimana tahap ini terdiri atas pembuatan karakter dan cerita menggunakan sofware Macromedia Flash MX..

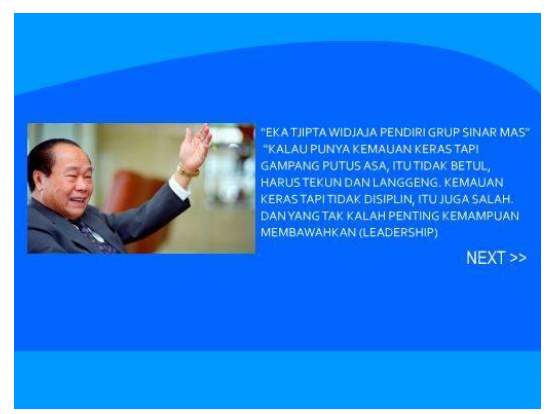

Gambar 8. Materi inspirasi wirausaha

Gambar di atas menunjukkan Game Simulasi Wirausaha Toko Cupcake dengan menunjukkan quote-quote inspirasi usaha materi-materi karakterisitk kewirausahaan pada SMK kelas XI



Gambar 9. Game perijinan usaha pada Game simulasi wirausaha toko cupcake

Gambar di atas menunjukkan Game perijinan usaha dengan cara mencari dokumen-dokumen yang dibutuhkan untuk membuat SIUP ataupun TDP

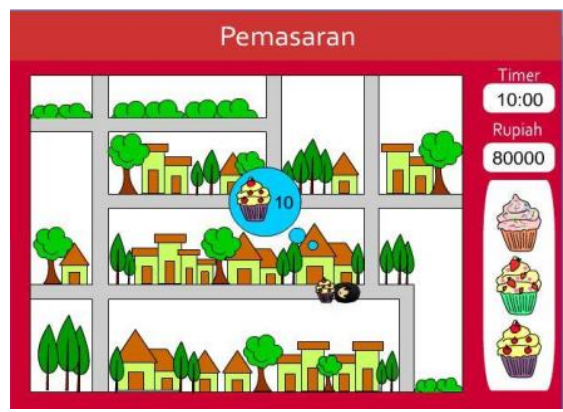

Gambar 10. Game pemasaran delivery by order

Gambar di atas menunjukkan Game pemasaran dan pengiriman cupcake sesuai tempat pemesan, jika sesuai dengan waktu yang ditetapkan maka akan mendapat bonus



Gambar 11. Game produksi memasak cupcake

Gambar di atas menunjukkan untuk Game produksi cupcake dengan cara memasak cupcake berdasarkan resep yang dibutuhkan

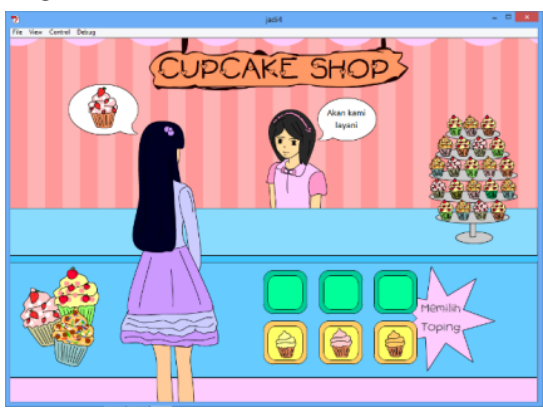

Gambar 12. penjualan cupcake di toko

Gambar di atas menunjukkan pelayanan penjualan cupcake di toko cupcake. Jika penjualan sesuai dengan target yang ditentukan akan mendapatkan bonus uang sebagai pembelian alat-alat produksi ataupun sarana pengembangan usaha.

\section{Tahap Pengujian}

Dalam pengembangan model pengajaran berbasis multimedia, maka uji validitas dimaksudkan untuk menguji sejauh mana model Game Simulasi Wirausaha Toko Cupcake yang dikembangkan dapat digunakan sebagai salah satu model media pengajaran, sehingga dapat diketahui tingkat kebenaran dan ketepatan penggunaan media tersebut

\section{Validasi ahli media}

Pada instrumen ahli media berisikan poin tentang aspek-aspek yang berhubungan dengan media pembelajaran. Instrument disebarkan 2 ahli media yaitu 1 dosen Teknik Informatika, dan 1 dosen desain grafis untuk memvalidasi Game Simulasi Wirausaha Toko Cupcake. Setelah data diperoleh, selanjutnya adalah menganalisis data tesebut. Penelitian ini lebih menitikberatkan pada bagaimana mengembangkan media pembelajaran sehingga data dianalisis dengan sistem deskriptif persentase. Untuk menganalisis data hasil checklist dilakukan langkah-langkah sebagai berikut:

1) Mengkuantitatifkan hasil checking sesuai dengan indikator yang telah ditetapkan dengan memberikan skor sesuai dengan bobot yang telah ditentukan sebelumnya. 
Sangat Baik $\quad=5$

Baik $\quad=4$

Cukup $\quad=3$

Kurang $\quad=2$

Sangat Kurang $=1$

2) Membuat tabulasi data.

3) Menghitung persentase dari tiap-tiap sub variabel dengan rumus:

$\mathrm{P}(\mathrm{s})=\mathrm{S} / \mathrm{N} \times 100 \%$

$\mathrm{P}(\mathrm{s})=$ persentase sub variable

$\mathrm{S}=$ jumlah skor tiap sub variabel

$\mathrm{N}=$ jumlah skor maksimum

4) Dari persentase yang telah diperoleh kemudian ditransformasikan ke dalam tabel supaya pembacaan hasil penelitian menjadi mudah.

5) Menentukan interval yang dikehendaki

Adapun hasil tabel validasi dapat dilihat pada Tabel 1 sebagai berikut

Tabel 1 .Tabel Validasi ahli media

\begin{tabular}{|c|c|c|c|c|c|}
\hline No & Pertanyaan & 1 & 2 & $\begin{array}{l}\text { juml } \\
\text { ah }\end{array}$ & $\begin{array}{l}\text { prosent } \\
\text { ase }\end{array}$ \\
\hline 1 & Manfaat Navigasi & 3 & 4 & 7 & $70 \%$ \\
\hline 2 & Ketepatan navigasi & 4 & 3 & 7 & $70 \%$ \\
\hline 3 & Kemudahan pengoperasian & 4 & 3 & 7 & $70 \%$ \\
\hline 4 & Keterkaitan gambar dan materi & 4 & 4 & 8 & $80 \%$ \\
\hline 5 & $\begin{array}{l}\text { Penggunaan bahasa mudah } \\
\text { dimengerti }\end{array}$ & 3 & 4 & 7 & $70 \%$ \\
\hline 6 & $\begin{array}{l}\text { Kemudahan pemilihan } \\
\text { jawaban }\end{array}$ & 4 & 4 & 8 & $80 \%$ \\
\hline 7 & Kemudahan navigasi & 3 & 4 & 7 & $70 \%$ \\
\hline 8 & $\begin{array}{l}\text { Kemudahan umpan balik bagi } \\
\text { siswa }\end{array}$ & 4 & 3 & 7 & $70 \%$ \\
\hline 9 & $\begin{array}{l}\text { Kemudahan dalam mencari } \\
\text { informasi }\end{array}$ & 4 & 4 & 8 & $80 \%$ \\
\hline 10 & Ketersediaan petunjuk & 3 & 3 & 6 & $60 \%$ \\
\hline 11 & Pengaturan tata letak menu & 5 & 4 & 9 & $90 \%$ \\
\hline 12 & Kompatibilitas & 5 & 4 & 9 & $90 \%$ \\
\hline 13 & $\begin{array}{l}\text { Pemaketan program media } \\
\text { pembelajaran }\end{array}$ & 5 & 4 & 9 & $90 \%$ \\
\hline 14 & Kualitas teks & 5 & 4 & 9 & $90 \%$ \\
\hline 15 & Keterbacaan tulisan teks & 4 & 4 & 8 & $80 \%$ \\
\hline 16 & Ketepatan ukuran huruf & 4 & 4 & 8 & $80 \%$ \\
\hline 17 & Ketepatan warna huruf & 4 & 4 & 8 & $80 \%$ \\
\hline 18 & Ketepatan jenis huruf & 4 & 4 & 8 & $80 \%$ \\
\hline 19 & Kualitas Bahan ajar & 4 & 4 & 8 & $80 \%$ \\
\hline 20 & Kesesuaian tampilan & 4 & 4 & 8 & $80 \%$ \\
\hline 21 & Kejelasan tata letak gambar & 4 & 4 & 8 & $80 \%$ \\
\hline 22 & Kesesuaian tampilan & 4 & 4 & 8 & $80 \%$ \\
\hline 23 & Kesesuaian tampilan & 4 & 4 & 8 & $80 \%$ \\
\hline 24 & Ketepatan penggunan tema & 4 & 4 & 8 & $80 \%$ \\
\hline 25 & Kualitas tempilan design & 4 & 4 & 8 & $80 \%$ \\
\hline 26 & $\begin{array}{l}\text { Kesesuaian warna tulisan } \\
\text { dengan background }\end{array}$ & 5 & 5 & 10 & $100 \%$ \\
\hline 27 & kualitas audio & 5 & 4 & 9 & $90 \%$ \\
\hline
\end{tabular}

Adapun perhitungan prosentase manfaat navigasi adalah sebagai berikut :

$$
\begin{aligned}
\mathrm{P}(\mathrm{s}) & =\mathrm{S} / \mathrm{N} \times 100 \% \\
& =7 / 10 \times 100 \%=70 \%
\end{aligned}
$$

Sedangkan poin-poin selanjutnya berdasarkan perhitungan yang sama. Berdasarkan Tabel 1 di atas maka yang memiliki nilai sangat baik yaitu pengaturan tata letak menu(90\%), kompatibilitas(90\%), pemaketan program media pembelajaran(90\%), kualitas teks(90\%) dan kesesuaian warna tulisan dengan background (100\%). Sedangkan nilai yang cukup rendah yaitu manfaat navigasi $(70 \%)$, ketepatan navigasi $(70 \%)$, kemudahan pengoperasian(70\%), penggunaan bahasa mudah dimengerti(70\%), kemudahan umpan balik siswa(70\%) dan kemudahan navigasi(70\%). Dan adapun saran revisi dari ahli media yaitu perlu dilengkapi petunjuk penggunaan Game dan juga memberikan latihan soal yang lebih banyak. Sedangkan hasil rata-rata prosentase keseluruhan yaitu $80 \%$ dengan hasil baik. Interval penilaian presentase sebagai berikut :
$85 \% \leq$ skor $\leq 100 \%$
:Sangat baik
$69 \% \leq$ skor $\leq 84 \%$
:Baik
$53 \% \leq$ skor $\leq 68 \%$
:Cukup
$37 \% \leq$ skor $\leq 52 \%$
:Kurang Baik
$20 \%<$ skor $36 \%$
:Tidak Baik

\section{Validasi ahli materi}

Pada instrumen validasi ahli materi berisikan poin tentang aspek-aspek yang berhubungan dengan materi media pembelajaran meliputi dari aspek pembelajaran, materi dan Kebenaran isi. Pada validasi ahli materi telah disebarkan ke 5 ahli materi yaitu guru kewirausahaan pada SMK kelas XI. Adapun perhitungan kuisioner validasi ahli materi sama dengan validasi ahli media. Hasil tabulasi perhitungan kuisioner perhitungan validasi ahli materi dapat dilihat pada Tabel 2.

\begin{tabular}{|c|c|c|c|c|c|c|c|c|}
\hline No & Pertanyaan & 1 & 2 & 3 & 4 & 5 & $\begin{array}{l}\mathrm{ju} \\
\mathrm{ml} \\
\mathrm{ah}\end{array}$ & $\begin{array}{l}\text { pros } \\
\text { enta } \\
\text { se }\end{array}$ \\
\hline 1 & $\begin{array}{l}\text { Kesesuaian materi } \\
\text { dengan standar } \\
\text { kompetensi }\end{array}$ & 4 & 5 & 4 & 5 & 4 & 22 & $88 \%$ \\
\hline 2 & $\begin{array}{l}\text { Kesesuaian indikator } \\
\text { dengankompetensi } \\
\text { dasar }\end{array}$ & 3 & 5 & 3 & 5 & 5 & 21 & $84 \%$ \\
\hline 3 & $\begin{array}{l}\text { Kejelasan petunjuk } \\
\text { belajar }\end{array}$ & 4 & 5 & 4 & 5 & 4 & 22 & $88 \%$ \\
\hline 4 & $\begin{array}{l}\text { Pemberian contoh- } \\
\text { contoh dalam penyajian } \\
\text { materi }\end{array}$ & 5 & 4 & 5 & 4 & 5 & 23 & $92 \%$ \\
\hline 5 & $\begin{array}{l}\text { Pemberian latihan } \\
\text { untukpemahaman } \\
\text { konsep }\end{array}$ & 4 & 5 & 4 & 5 & 4 & 22 & $88 \%$ \\
\hline 6 & $\begin{array}{l}\text { Kegiatan pembelajaran } \\
\text { dapat memotivasi siswa }\end{array}$ & 5 & 5 & 5 & 5 & 5 & 25 & $\begin{array}{r}100 \\
\% \\
\end{array}$ \\
\hline 7 & $\begin{array}{l}\text { Memberikan } \\
\text { kesempatan siswa } \\
\text { untuk berlatih sendiri }\end{array}$ & 5 & 4 & 5 & 4 & 5 & 23 & $92 \%$ \\
\hline 8 & $\begin{array}{l}\text { Pembelajarannya } \\
\text { memperhatikan } \\
\text { perbedaan individu }\end{array}$ & 3 & 4 & 3 & 4 & 3 & 17 & $68 \%$ \\
\hline 9 & $\begin{array}{l}\text { Kesesuaian dengan } \\
\text { kurikulum }\end{array}$ & 5 & 4 & 5 & 4 & 5 & 23 & $92 \%$ \\
\hline 10 & Kebenaran materi & 4 & 4 & 4 & 4 & 4 & 20 & $80 \%$ \\
\hline 11 & Keterkinian materi & 3 & 4 & 3 & 4 & 4 & 18 & $72 \%$ \\
\hline 12 & Kemenarikan materi & 4 & 4 & 4 & 4 & 4 & 20 & $80 \%$ \\
\hline 13 & Kedalaman materi & 5 & 4 & 5 & 4 & 5 & 23 & $92 \%$ \\
\hline 14 & Keruntutan materi & 4 & 4 & 4 & 4 & 4 & 20 & $80 \%$ \\
\hline 15 & Cakupan materi & 4 & 4 & 4 & 4 & 4 & 20 & $80 \%$ \\
\hline
\end{tabular}

Tabel 2 Tabel validasi ahli materi 


\begin{tabular}{lllllllll}
\hline 16 & $\begin{array}{l}\text { Kemudahan untuk } \\
\text { dipahami }\end{array}$ & 4 & 3 & 4 & 4 & 3 & 18 & $72 \%$ \\
\hline 17 & Pemberian evaluasi & 5 & 4 & 5 & 4 & 4 & 22 & $88 \%$ \\
\hline & $\begin{array}{l}\text { Pengukuran } \\
\text { kemampuan siswa }\end{array}$ & 5 & 3 & 3 & 3 & 4 & 18 & $72 \%$ \\
\hline 19 & Pemberian umpan balik & 5 & 4 & 5 & 4 & 5 & 23 & $92 \%$ \\
\hline & $\begin{array}{l}\text { Ketepatan penggunaan } \\
\text { bahasa }\end{array}$ & 3 & 4 & 3 & 4 & 3 & 17 & $68 \%$ \\
\hline $\begin{array}{l}\text { Kemudahan siswa } \\
\text { memahami Bahasa }\end{array}$ & 3 & 4 & 3 & 4 & 3 & 17 & $68 \%$ \\
\hline & $\begin{array}{l}\text { Pemberian motivasi } \\
\text { belajar }\end{array}$ & 3 & 4 & 3 & 4 & 3 & 17 & $68 \%$ \\
\hline
\end{tabular}

Berdasarkan perhitugan kuisioner pada Tabel 2 di atas yang memiliki nilai baik dengan nilai sangat baik di atas $90 \%$ yaitu pemberian contoh-contoh dalam peyajian materi(92\%), kegiatan pembelajaran dapat memotivasi siswa(100\%), kesesuaian dengan kurikulum(92\%), kedalaman materi(92\%), dan pemberian umpan balik(92\%). Sedangkan nilai yang cukup rendah di bawah $70 \%$ yaitu ketepatan penggunaan bahasa(68\%), kemudahan siswa memahami bahasa(68\%), dan pemberian motivasi belajar(68\%). Sedangkan hasil rata-rata prosentasi keseluruhan pada validasi ahli materi yaitu $82 \%$ dengan hasil baik. Interval penilaian prosentase sebagai berikut :

$85 \% \leq$ skor $\leq 100 \%$

$69 \% \leq$ skor $\leq 84 \%$

:Sangat baik

$53 \% \leq$ skor $\leq 68 \%$

:Baik

$37 \% \leq$ skor $\leq 52 \%$

:Cukup

:Kurang Baik

$20 \%<$ skor $36 \%$

:Tidak Baik

\section{Validasi Siswa}

Pada instrumen validasi siswa berisikan poin tentang aspek yang berhubungan dengan poin motivasi, kemenarikan, kemudahan dan kemanfaatan. Penyebaran kuisioner terhadap 112 siswa di SMK kelas XI. Adapun perhitungan kuisioner validasi siswa sama dengan validasi ahli media. Adapun indikator jawaban validasi siswa yaitu :

$\begin{array}{ll}\text { Sangat Bagus } & : 4 \\ \text { Bagus } & : 3 \\ \text { Cukup } & : 2 \\ \text { Buruk } & : 1\end{array}$

Hasil tabulasi perhitungan kuisioner perhitungan validasi ahli materi dapat dilihat pada Tabel 2.Adapun Untuk tampilan tabel perhitungan kuisoner siswa tidak menunjukkan hasil jawan indikator siswa karena banyaknya siswa yang mengisi kuisioner. Oleh karena itu tabel hanya menampilkan pertanyaan, jumlah dan prosentase. Perhitungan kuisioner dapat dilihat pada Tabel 3 sebagai berikut :

Tabel 3. Tabel peritungan kuisioner oleh siswa

\begin{tabular}{rlrc}
\hline No & Peratanyaan & Jumlah & $\begin{array}{l}\text { Prose } \\
\text { ntase }\end{array}$ \\
\hline 1 & $\begin{array}{l}\text { Saya ingin belajar mata pelajaran } \\
\text { kewirausahaan lebih serius }\end{array}$ & 85 & $76 \%$ \\
\hline & $\begin{array}{l}\text { Saya merasa belajar kewirausahaan } \\
\text { penting }\end{array}$ & 97 & $87 \%$ \\
\hline & $\begin{array}{l}\text { Saya ingin belajar kewirausahaan dengan } \\
\text { cara menyeselesaikan soal-soal } \\
\text { kewirausahaan }\end{array}$ & & \\
\hline
\end{tabular}

\begin{tabular}{|c|c|c|c|}
\hline 4 & $\begin{array}{l}\text { Saya merasa bersemangat untuk mengikuti } \\
\text { pelajaran kewirausahaan }\end{array}$ & 79 & $71 \%$ \\
\hline 5 & Saya merasa siap menghadapi ulangan & 77 & $69 \%$ \\
\hline 6 & $\begin{array}{l}\text { Saya lebih terampil menggunakan } \\
\text { komputer }\end{array}$ & 85 & $76 \%$ \\
\hline 7 & Saya lebih lancar menggunakan mouse & 90 & $80 \%$ \\
\hline 8 & $\begin{array}{l}\text { Saya mempunyai ketrampilan baru yaitu } \\
\text { berupa menggunakan komputer }\end{array}$ & 86 & $89 \%$ \\
\hline 9 & $\begin{array}{l}\text { Saya merasa senang mendapat tugas } \\
\text { kewirausahaan }\end{array}$ & 68 & $61 \%$ \\
\hline 10 & $\begin{array}{l}\text { Saya merasa lebih berguna mengisi waktu } \\
\text { luang dengan belajar materi pelajaran } \\
\text { kewirausahaan menggunakan bahan ajar } \\
\text { multimedia interaktif kewirausahaan }\end{array}$ & 73 & $65 \%$ \\
\hline 11 & $\begin{array}{l}\text { Saya merasa senang belajar pelajaran } \\
\text { dengan menggunakan bahan ajar } \\
\text { multimedia interaktif kewirausahaan }\end{array}$ & 82 & $73 \%$ \\
\hline 12 & $\begin{array}{l}\text { Saya merasa senang belajar pelajaran } \\
\text { kewirausahaan dengan menggunakan } \\
\text { bahan ajar multimedia interaktif } \\
\text { kewirausahaan }\end{array}$ & 86 & $77 \%$ \\
\hline 13 & $\begin{array}{l}\text { Saya selalu mencoba mengerjakan soal } \\
\text { kembali bahan ajar multimedia interaktif } \\
\text { kewirausahaan meskipun jawabannya } \\
\text { selalu salah }\end{array}$ & 76 & $68 \%$ \\
\hline 14 & $\begin{array}{l}\text { Saya merasa termotivasi agar mendapat } \\
\text { nilai tertinggi dalam bahan ajar } \\
\text { multimedia intera }\end{array}$ & 85 & $76 \%$ \\
\hline 15 & $\begin{array}{l}\text { Saya merasa bisa mendapatkan skor } \\
\text { tertinggi dalam pelajaran kewirausahaan } \\
\text { menggunakan bahan ajar multimedia } \\
\text { interaktif kewirausahaan }\end{array}$ & 87 & $78 \%$ \\
\hline 16 & $\begin{array}{l}\text { Saya merasa tertarik dengan tampilan } \\
\text { bahan ajar multimedia interaktif } \\
\text { kewirausahaan }\end{array}$ & 80 & $71 \%$ \\
\hline 17 & $\begin{array}{l}\text { Saya merasa tertarik dengan model game } \\
\text { yang ada di bahan ajar multimedia } \\
\text { interaktif kewirausahaan }\end{array}$ & 82 & $73 \%$ \\
\hline 18 & $\begin{array}{l}\text { Saya merasa tertarik pada animasi pada } \\
\text { bahan ajar multimedia interaktif } \\
\text { kewirausahaan }\end{array}$ & 85 & $76 \%$ \\
\hline 19 & $\begin{array}{l}\text { Saya lebih tertarik belajar menggunakan } \\
\text { bahan ajar multimedia interaktif } \\
\text { kewirausahaan daripada menggunakan } \\
\text { buku panduan mata pelajaran } \\
\text { kewirausahaan }\end{array}$ & 92 & $82 \%$ \\
\hline 20 & $\begin{array}{l}\text { Saya merasa tertarik untuk selalu } \\
\text { memainkan game pada bahan ajar } \\
\text { multimedia interaktif kewirausahaan }\end{array}$ & 81 & $72 \%$ \\
\hline 21 & $\begin{array}{l}\text { Saya merasa tertarik untuk mempunyai } \\
\text { lebih banyak game edukasi pada bahan } \\
\text { ajar multimedia interaktif }\end{array}$ & 89 & $79 \%$ \\
\hline 22 & $\begin{array}{l}\text { Saya mudah memahami materi mata } \\
\text { pelajaran kewirausahaan pada bahan ajar } \\
\text { multimedia interaktif kewirausahaan }\end{array}$ & 85 & $76 \%$ \\
\hline 23 & $\begin{array}{l}\text { Saya mudah menghafal materi pelajaran } \\
\text { kewirausahaan pada bahan ajar } \\
\text { multimedia interaktif kewirausahaan }\end{array}$ & 75 & $67 \%$ \\
\hline 24 & $\begin{array}{l}\text { Saya mudah menjawab soal materi } \\
\text { kewirausahaan setelah menggunakan } \\
\text { bahan ajar multimedia interaktif } \\
\text { kewirausahaan }\end{array}$ & 83 & $74 \%$ \\
\hline 25 & $\begin{array}{l}\text { Saya mudah mengoperasikan bahan ajar } \\
\text { multimedia interaktif kewirausahaan }\end{array}$ & 78 & $70 \%$ \\
\hline 26 & $\begin{array}{l}\text { Saya mudah memahami simulasi cara } \\
\text { bermain bahan ajar multimedia interaktif } \\
\text { kewirausahaan }\end{array}$ & 82 & $73 \%$ \\
\hline 27 & $\begin{array}{l}\text { Setelah menggunakan bahan ajar } \\
\text { multimedia interaktif kewirausahaan maka } \\
\text { saya ingin berwirausaha }\end{array}$ & 81 & $72 \%$ \\
\hline 28 & $\begin{array}{l}\text { Dengan bahan ajar multimedia interaktif } \\
\text { kewirausahaan mampu meningkatkan } \\
\text { kemampuan berwirausaha }\end{array}$ & 87 & $78 \%$ \\
\hline
\end{tabular}


Berdasarkan perhitugan kuisioner pada tabel 3 di atas yang memiliki nilai baik dengan nilai sangat sangat baik di atas $80 \%$ yaitu pentingnya belajar kewirausahaan(87\%), ketrampilan baru yaitu menggunakan komputer(89\%) dan lebih tertarik belajar menggunakan bahan ajar multimedia interaktif kewirausahaan daripada menggunakan buku panduan mata pelajaran kewirausahaan $(82 \%)$. Sedangkan nilai yang cukup rendah di bawah $70 \%$ yaitu merasa siap menghadapi ulangan(69\%), Senang mendapat tugas kewirausahaan(61\%) dan mudah menghafal materi pelajaran kewirausahaan pada bahan ajar multimedia interaktif kewirausahaan(67\%). Sedangkan hasil rata-rata prosentasi keseluruhan pada validasi siswa yaitu $74 \%$ dengan hasil bagus. Interval penilaian pada kuisioner validasi siswa adalah sebagai berikut :

$\begin{array}{ll}76<\text { skor }<100 & \text { :Sangat Bagus } \\ 51<\text { skor }<75 & \text { :Bagus } \\ 26<\text { skor }<50 & \text { :Cukup } \\ 0<\text { skor }<25 & \text { :Buruk }\end{array}$

\section{KESIMPULAN DAN SARAN}

\section{Kesimpulan}

Adapun kesimpulan dari penelitian yaitu :

1. Berdasarkan validasi ahli media maka yang memiliki nilai sangat baik yaitu pengaturan tata letak menu(90\%), kompatibilitas(90\%), pemaketan program media pembelajaran $(90 \%)$, kualitas tek(90\%)s dan kesesuaian warna tulisan dengan background(100\%). Sedangkan nilai yang cukup rendah yaitu manfaat navigasi(70\%), ketepatan navigasi(70\%), kemudahan pengoperasian $(70 \%)$, penggunaan bahasa mudah dimengerti(70\%), kemudahan umpan balik siswa $(70 \%)$ dan kemudahan navigasi(70\%). Dan adapun saran revisi dari ahli media yaitu perlu dilengkapi petunjuk penggunaan Game dan juga memberikan latihan soal yang lebih banyak. Sedangkan hasil rata-rata prosentase keseluruhan yaitu $80 \%$ dengan hasil baik

2. Berdasarkan validasi ahli materi maka yang memiliki nilai baik dengan nilai sangat baik di atas $90 \%$ yaitu pemberian contoh-contoh dalam peyajian materi(92\%), kegiatan pembelajaran dapat memotivasi siswa(100\%), kesesuaian dengan kurikulum(92\%), kedalaman materi(92\%), dan pemberian umpan balik $(92 \%)$. Sedangkan nilai yang cukup rendah di bawah $70 \%$ yaitu ketepatan penggunaan bahasa(68\%), kemudahan siswa memahami bahasa(68\%), dan pemberian motivasi belajar(68\%). Sedangkan hasil rata-rata prosentasi keseluruhan pada validasi ahli materi yaitu $82 \%$ dengan hasil baik.

3. Berdasarkan hasil validasi siswa yang memiliki nilai baik dengan nilai sangat sangat baik di atas $80 \%$ yaitu pentingnya belajar kewirausahaan(87\%), ketrampilan baru yaitu menggunakan komputer(89\%) dan lebih tertarik belajar menggunakan bahan ajar multimedia interaktif kewirausahaan daripada menggunakan buku panduan mata pelajaran kewirausahaan(82\%). Sedangkan nilai yang cukup rendah di bawah $70 \%$ yaitu merasa siap menghadapi ulangan(69\%), Senang mendapat tugas kewirausahaan(61\%) dan mudah menghafal materi pelajaran kewirausahaan pada bahan ajar multimedia interaktif kewirausahaan(67\%). Sedangkan hasil rata-rata prosentasi keseluruhan pada validasi siswa yaitu $74 \%$ dengan hasil bagus

4. Validasi ahli materi memiliki respon lebih baik dibandingkan validasi ahli materi. Berdasarkan hal tersebut maka materi perlu ditambahkan petunjuk penggunaan game serta menggunakan bahasa yang mudah dimengerti.

\section{Saran}

Adapun saran dari penelitian ini yaitu :

Game Simulasi Wirausaha Toko Cupcake ditambahkan Game 3D sehingga lebih menari

\section{DAFTAR PUSTAKA}

Cahyadi,D (2014). Pengembangan media pembelajaran Berbasis Flash pada mata pelajaran IPA Terpadu Pokok bahasan wujud zat dan perubahannya kelas VII SMPN 5 Satu Atap Bumiwijaya. Skripsi. Universitas Negeri Semarang

DILLON, T. (2004, December). Adventure Game for Learning and Storytelling. Retrieved Februari 17, 2010, from Futurelab Innovation in Education :http://www.futurelab.org.uk/projects/adventureauthor/context

Kementerian Pendidikan Nasional. 2009. Rencana Strategis Kementerian Pendidikan Nasional 20102014. Departemen Pendidikan Nasional. Jakarta KOLBb, D.A. (1984): Experiential learning: experience as the source of learning and development. Englewood Cliffs, NJ: Prentice Hall.

LASTARAWATI, B. 2012. Pentingnya kelas kewirausahaan pada SMK pariwisata. Jurnal Pendidikan Vokasi, Vol 2, Nomor 1.

MOEIS.A.O . 2005. Jurnal Teknologi, Edisi Khusus No.2 Teknik Industri tahun XIX, Juli 2005, ISSN 02151685

WAHONO..R,S. 2006. Aspek Dan Kriteria Penilaian Media Pembelajaran http://romisatriawahono.net/2006/06/21/aspekdan-kriteria-penilaian-media-pembelajaran/ diakses 6 Juni 2014

STRANGMAN, N., \& Hall, T. (2003). Virtual Reality Computer Simulations. National Center on Accessing the General Curriculum 2.

VIRVOU, M. (2005). Combining Software Games with Education: Evaluation of Its Educational Effectivinnes. Journal Educational Technology and Society, 8 (2), 54-65. 